Reprod. Nutr. Dévelop., 1988, 28 (2 A), 293-301.

\title{
Effect of pectic substances on prolactin and growth hormone secretion in the ewe and on the induction of casein synthesis in the rat
}

\author{
L. SAWADOGO, L.-M. HDUDEBINE (1), J.-F. THIBAULT (*), X. ROUAU, \\ M. OLLIVIER-BOUSQUET
}

Laboratoire de Physiologie de la Lactation I.N.R.A., 78350 Jouy-en-Josas, France.

${ }^{*}$ ) Laboratoire de Biochimie et Technologie des Glucides I.N.R.A., rue de la Géraudière, 44072 Nantes, France.

Summary. Pectins from apple, citrus and sugar beet injected intravenously to ewes markedly stimulated blood prolactin, growth hormone $(\mathrm{GH})$ and cortisol. Pectic acid and polygalacturonic acid exhibited the same property. A preparation of oligogalacturonic acid with a polymerisation degree of 12 to 13 was also active, whereas oligomers with a smaller degree of polymerisation $(\simeq 10)$ were devoid of activity. Pectic acid administered orally to mature virgin rats induced the accumulation of $\beta$-casein in mammary gland. Pectins and some of their derivatives therefore had a lactogenic property and their effect probably resulted from a capacity to trigger lactogenic hormone secretion.

\section{Introduction.}

Various plant extracts are traditionally used for their pharmacological properties : some are reputed to be lactogenic and are absorbed accordingly. Only a few quantitative evaluations of this property have been performed so far, and some people still doubt that this traditional practise is justified. However, a recent study (Sawadogo et al., submitted for publication) has shown that various plant extracts are really able to (1) induce casein synthesis when administered orally to rats, (2) markedly stimulate prolactin, growth hormone $(\mathrm{GH})$ and cortisol secretion when injected intravenously into ewes. These three hormones are involved in the induction or stimulation of milk secretion (Houdebine, 1986). The stimulation of their secretion by plant extracts could therefore account for their effects on mammary gland. A chemical analysis of fractions with enriched lactogenic activity has revealed that most contain a large quantity of pectin (Sawadogo et al., submitted for publication). These observations led us to study pectins to determine if they could stimulate the secretion of lactogenic hormones and induce milk synthesis. The experimental facts reported here show that this is indeed the case. Pectins were shown to have the unexpected property to stimulate milk secretion.

(1) To whom correspondance should be addressed. 


\section{Material and methods.}

Origin of pectins and their derivatives. - Apple and citrus pectins and pectic acid were from Fluka. Sugar beet pectin was prepared by J.-F. Thibault (Thibault and Rombouts, 1986). Galacturonic acid was from Sigma and Fluka. Oligogalacturonic acids were prepared by J.-F. Thibault (Thibault, 1983).

Measurement of hormone secretion. - All substances were dissolved in $5 \mathrm{ml}$ of $0.7 \% \mathrm{NaCl}$ and neutralized with $\mathrm{IM} \mathrm{NaOH}$. After neutralization and before injection, the insoluble material was eliminated by centrifugation at $3000 \times \mathrm{g}$ for $15 \mathrm{~min}$. The fractions were injected into the jugular vein of ewes at 9 a.m. Blood samples were collected one hour before and $2 \mathrm{~h}$ after injection (shown by an arrow on the graphs).

Ewe prolactin and $\mathrm{GH}$ were measured in plasma using radioimmunoassay (Kann, 1971). Cortisol was measured using binding to plasma protein (Bosc and Fèvre, 1977). Rat prolactin and GH were measured using the NIH kit.

Measurement of $\beta$-casein synthesis. - Pectic acid was dissolved in water and neutralized $(250 \mathrm{mg} / 5 \mathrm{ml}) .5 \mathrm{ml}$ were administered orally to 3 -month old virgin rats in the morning and evening for 4 days. At the end of the treatment, the
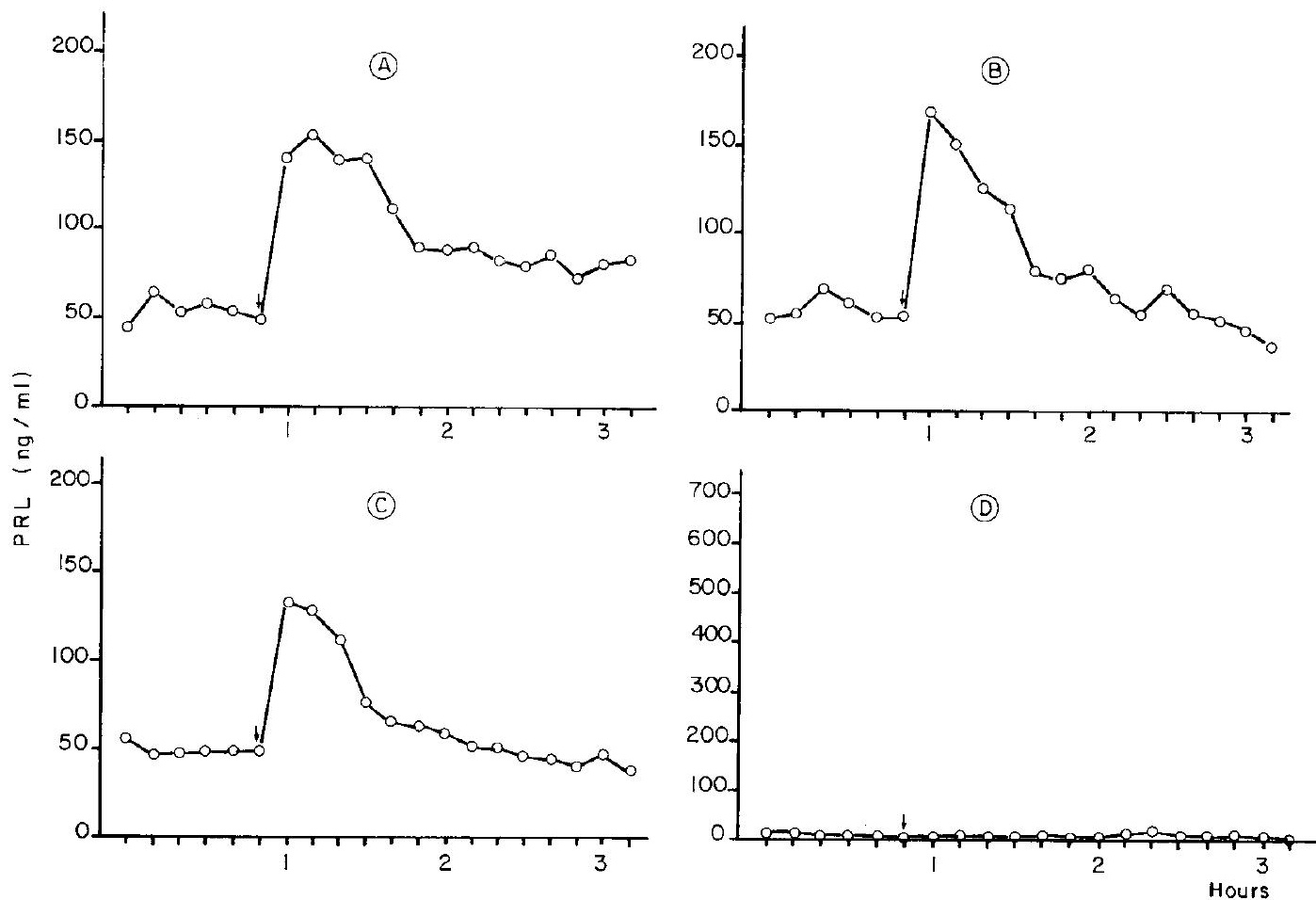

FIG. 1. - Effects of pectins on prolactin secretion. Pectins of various origins were dissolved in $0.7 \% \mathrm{NaCl}$ and injected intravenously into ewes as indicated by arrows. Prolactin was estimated in plasma as described in methods.

A) pectin from sugar-beet $(100 \mathrm{mg})$; B) pectin from apple $(200 \mathrm{mg})$; C) pectin from citrus $(200 \mathrm{mg}) ;$ D) $0.7 \% \mathrm{NaCl}$. 
inguinal mammary glands were collected and homogenized. The homogenate was clarified by centrifugation at $3000 \times \mathrm{g}$ for $15 \mathrm{~min}$. The content of the supernatant in $\beta$-casein was evaluated using a previously described radioimmunoassay (Edery et al., 1984 ; Sawadogo and Houdebine, 1987). Five animals were used in each group. The control animals were treated with $5 \mathrm{ml}$ of water. All results were the mean value $( \pm$ SEM) of the duplicates of five animals. The results refer to the total protein in clarified homogenates.

Measurement of $\beta$-casein secretion. - Casein secretion was measured essentially as described previously (Ollivier-Bousquet, 1983). Briefly, mammary tissue was explanted from lactating rabbits and small fragments were incubated for 3 min in the presence of $40 \mu \mathrm{Ci} / \mathrm{m}^{3} \mathrm{H}$-L-leucine, $35 \mathrm{Ci} /$ mmole (CEA, Saclay). The explants were then rinsed with the medium devoid of radioactivity and further incubated for 60 min. Labelled proteins in the tissue and the medium were then measured by scintillation counting.

\section{Results.}

Action of pectins on prolactin, GH and cortisol secretions. - Sugar beet, apple and citrus pectins were injected intravenously into ewes. The three types of pectins exhibited roughly the same capacity to stimulate prolactin secretion (fig. 1) ; they also triggered GH secretion but with lower efficiency (fig. 2). Sugar
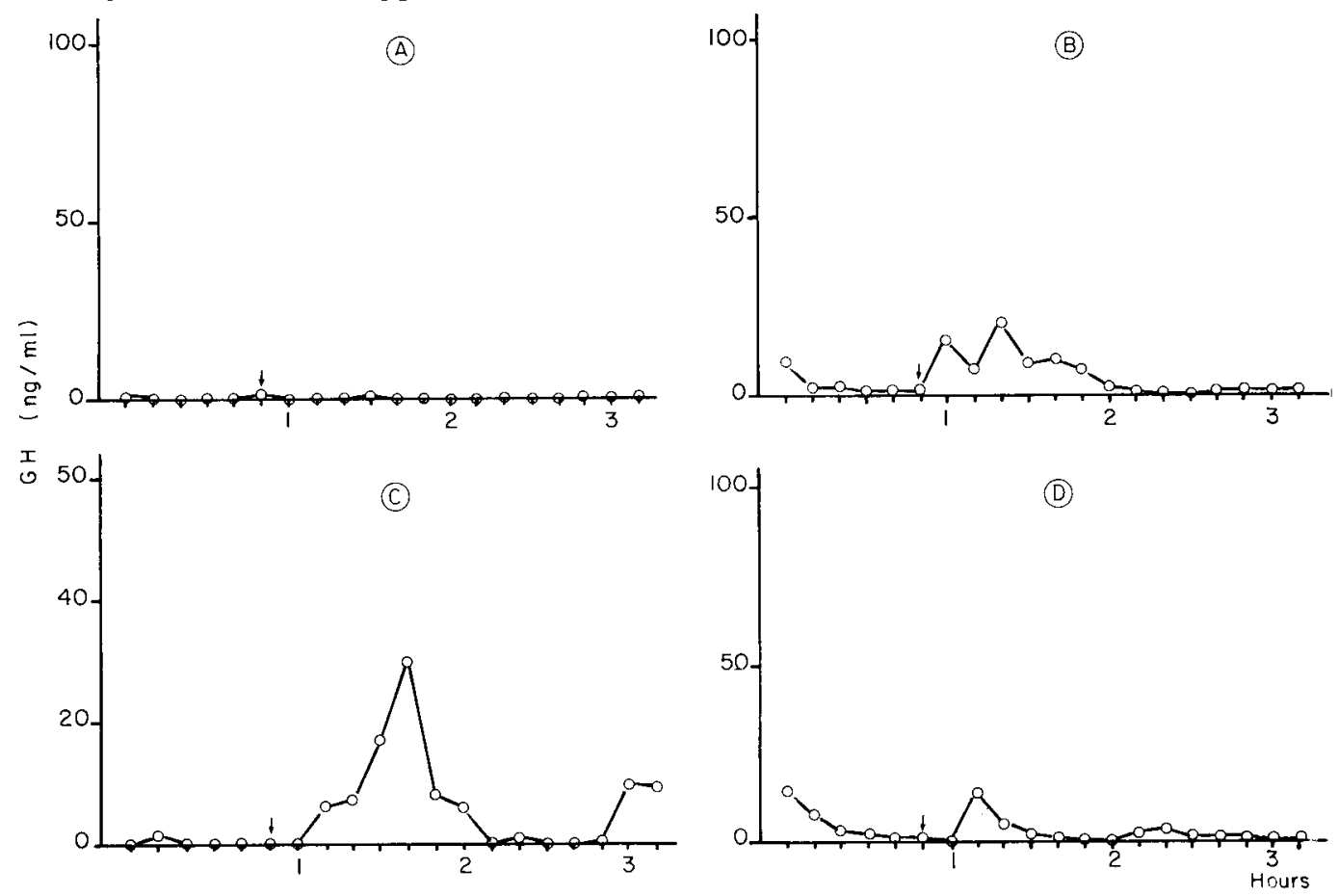

FIG. 2. - Effects of pectins on $\mathrm{GH}$ secretion. Conditions are those described in figure 1.

A) $0.7 \% \mathrm{NaCl} ;$ B) pectin from citrus $(100 \mathrm{mg}) ; C)$ pectin from sugar-beet $(200 \mathrm{mg})$; D) pectin from apple $(100 \mathrm{mg})$. 
beet pectin at a relatively low concentration (50 $\mathrm{mg} /$ injection) was also capable of stimulating cortisol secretion (fig. 3).

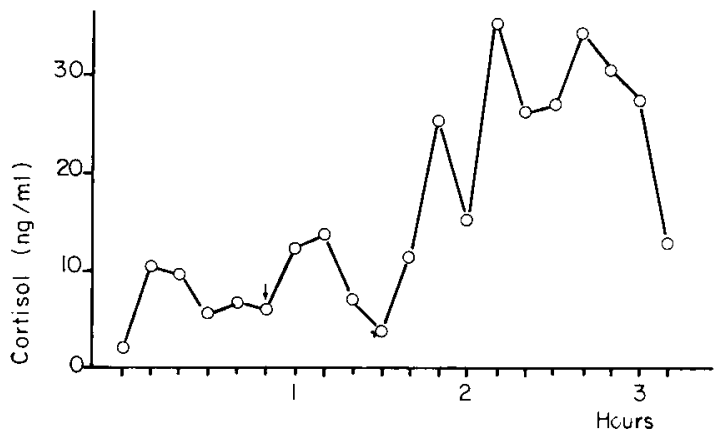

FIG. 3. - Effects of pectins on cortisol secretion. Pectin from sugar-beet $(50 \mathrm{mg})$ was injected into a ewe and cortisol was measured in blood as depicted in methods.
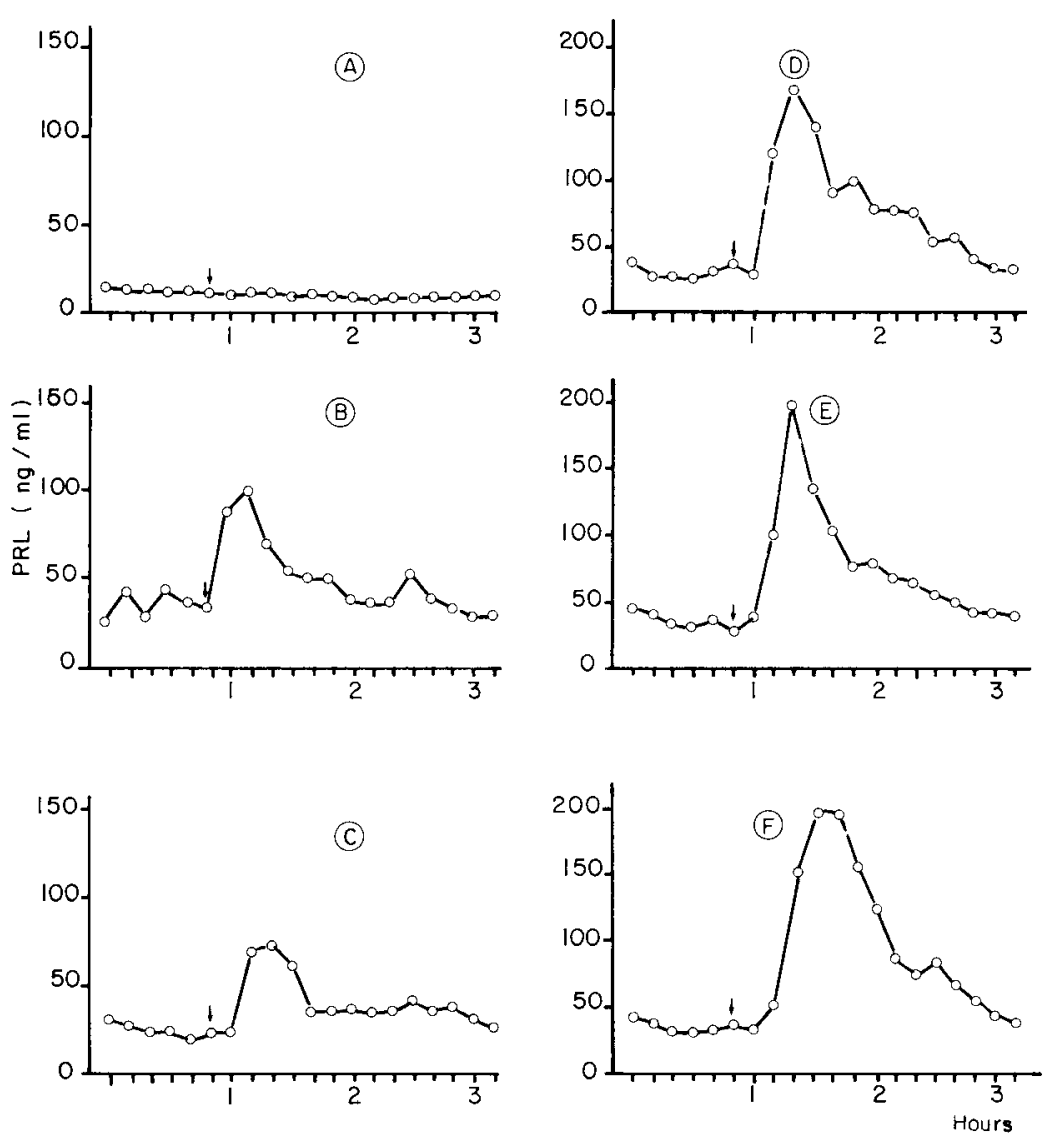

FIG. 4. - Effects of various amounts of pectic acid on the secretion of prolactin. Pectic acid was dissolved in $0.7 \% \mathrm{NaCl}$. The solution was neutralized and clarifie befor injection. In all cases, $5 \mathrm{ml}$ containing various amounts of pectic acid were injected.

A) $5 \mathrm{mg}$; B) $10 \mathrm{mg}$; C) $20 \mathrm{mg}$; D) $50 \mathrm{mg}$; E) $100 \mathrm{mg}$; F) $200 \mathrm{mg}$. 
A pectin fragment containing 12 to 13 molecules of galacturonic acid was still active, whereas a shorter fragment $(=10$ mers) containing no other oses but galacturonic acid remained ineffective (fig. 7).
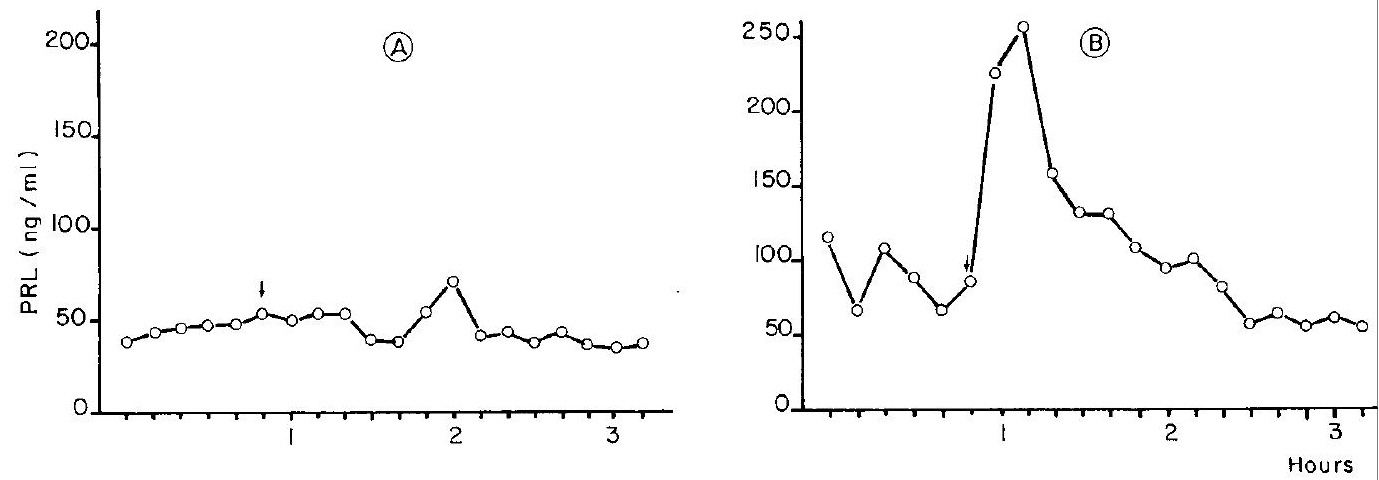

FIG. 7. - Effects of oligogalacturonic acid on prolactin secretion: conditions are those of figure 4.

A) Oligogalacturonic acid 10 mers $(100 \mathrm{mg}) ; \mathrm{B})$ Oligogalacturonic acid 12-13 mers $(200 \mathrm{mg})$.

Moreover, experiments not shown here in detail revealed that galacturonic acid in monomeric form, glucuronic acid, D-galactose, L-arabinose, rhamnose, alginic acid and arabinogalactan from larch (Fluka) were totally devoid of activity.

Action of pectic acid on casein synthesis. - Several plants which contain a principle capable of stimulating prolactin secretion have been tested for their possible action on milk secretion (Sawadogo and Houdebine, 1987). The experiments indicated that there was good agreement between both tests. Hence, it was expected that pectins and their derivatives which stimulate hormone secretion would also induce milk synthesis. The results of figure 8 clearly show that pectic acid administered orally to rats was lactogenic. In

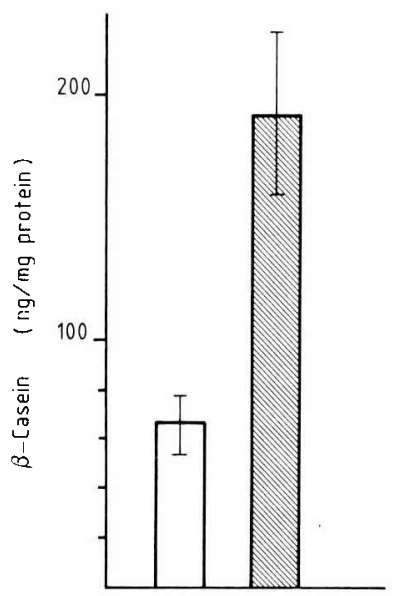

FIG. 8. -- Effects of pectic acid on the induction of $\beta$-casein synthesis. Pectic acid in solution was administered to mature virgin rats in the morning and the evening for 4 days $1250 \mathrm{mg}$ each time). At the end of treatment, $\beta$-casein in mammary gland was estimated using a radioimmunoassay. Results are the mean $( \pm S E M)$ of five animals in each group.

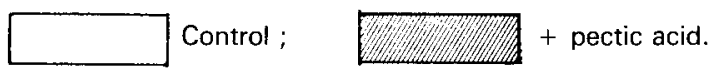


addition, the blood of animals receiving pectic acid contained more prolactin and $\mathrm{GH}$ (fig. 9).

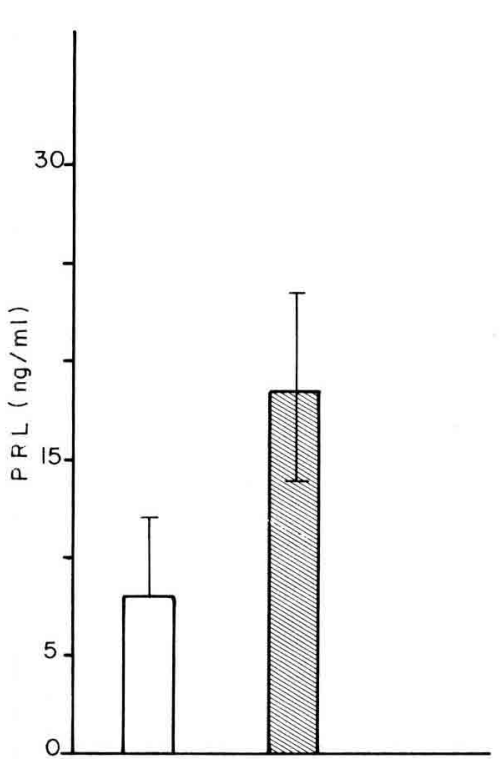

FIG. 9. - Effects of pectic acid administered orally on prolactin and $\mathrm{GH}$ secretion. Blood of the animals treated with water and pectic acid (fig. 8) was collected at the end of treatment (i.e., $1 \mathrm{~h} 30$ after the last administration of the products).
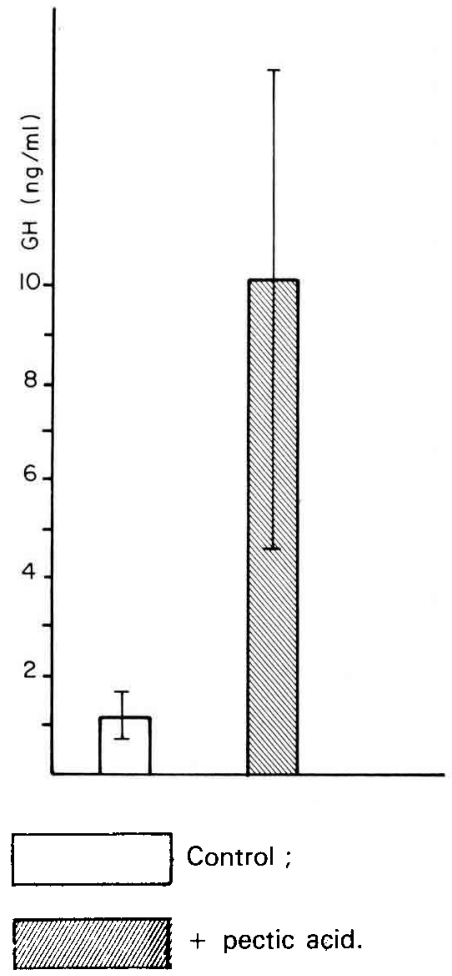

FIG. 10. - Effects of pectic acid on casein secretion. Mammary tissue was incubated in the presence of labelled leucine, as described in Methods. The tissue was then further incubated for $60 \mathrm{~min}$ in the presence or absence of pectic acid $(2.5 \mu \mathrm{g} / \mathrm{ml})$. Total synthesized protein in the tissue was evaluated after precipitation by trichloroacetic acid. Labelled secreted caseins were measured by precipitation of the medium at $\mathrm{pH}$ 4.6. Secreted caseins are expressed as the percentage of total labelled protein. Results are the mean $( \pm S E M)$ of four animals.

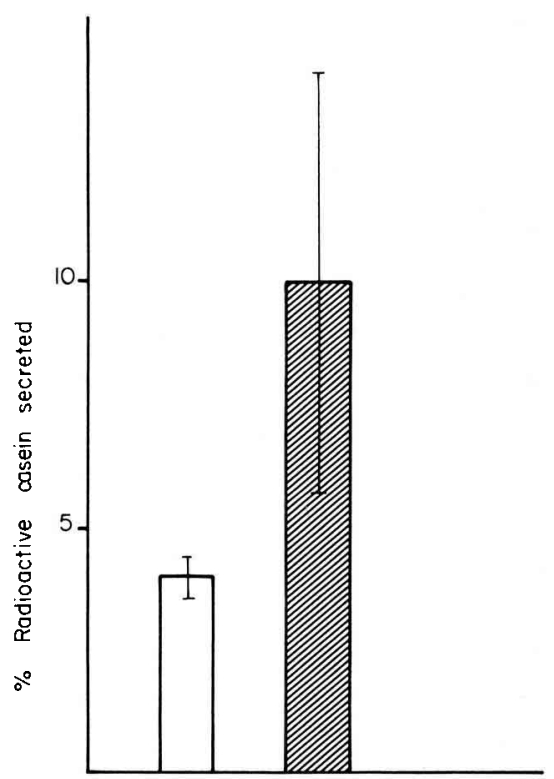


Action of pectic acid on casein secretion. - Pectin and other extracts are clearly potential stimulators of lactogenic secretion. Preliminary results (not shown here) revealed that these fractions also stimulated hormone secretion when added directly to isolated hypophysis. Several unrelated hormones were also released, suggesting that specific mechanisms controlling pituitary hormone secretion were probably not involved. Rather, these observations suggest that pectin acted as a relatively unspecific secretagogue. The results of figure 10 clearly show that pectic acid directly added to mammary explants stimulated casein secretion. This effect was totally independent of the induction of casein synthesis which could never be triggered in vitro by plant extracts (Sawadogo, 1987).

\section{Conclusions.}

The experimental results reported here clearly indicate that pectins and some of their derivatives have a lactogenic property. Numerous biological properties are attributed to pectins, e.g. detoxication, anti-cholesterolemia, healing. To the best of our knowledge, this is the first time that the lactogenic property of pectin has been reported. It is generally admitted that pectins added to food play an essentially passive role by delaying intestinal transit. The fact that pectins stimulate hormone secretion leads us to re-assess this question. It is indeed likely that some vegetal products, rich in pectins and added into food, stimulate milk production not only due to the energy they contain. If this is the case, it is logical to tentatively stimulate milk production by adding more or less purified pectins to the food of lactating female. More generally, since pectins stimulate the secretion of $\mathrm{GH}$, cortisol and other molecules it may be possible to modulate several biological functions other than lactation.

In most cases, the mechanism of pectin action is unknown. The experiments described in figure 10 suggest that they are potent stimulators of secretion. It remains to determine which cellular mechanisms are involved in this stimulation. The active part of pectin molecules is also unknown; experiments are in progress to determine which chemical structures are responsible.

The experiments reported here suggest that pectins or pectin fragments carry information which is understood by target cells. It is striking that various oligosaccharins, including pectin fragments derived from the plant cell wall, act as potent cellular messengers for the plant cells (Albersheim and Darvill, 1985).

Reçu en août 1987.

Accepté en novembre 1987.

Acknowledgements. - The technical help of Mrs Ahmed-Ali, Mr Daignault, Mr Durieux, Mrs Puissant and Mrs Vermeire is fully acknowledged.

Résumé. - Effets de substances pectiques sur la sécrétion de prolactine et d'hormone de croissance chez la brebis et sur l'induction de la synthèse de caséine chez la rate.

Des pectines de pomme, de citron et de betterave injectées par voie intraveineuse à des brebis stimulent de manière intense la concentration sanguine de prolactine, d'hormone 
de croissance $(\mathrm{GH})$ et de cortisol. L'acide pectique et l'acide polygalacturonique possèdent la même propriété. Une préparation d'acide oligogalacturonique ayant un degré de polymérisation moyen de 12-13 est également active tandis que des oligomères de degré de polymérisation plus petit $(=10)$ sont dépourvus d'activité. L'acide pectique administré par la voie orale à des rates vierges pubères induit l'accumulation de caséine- $\beta$ dans la glande mammaire. Les pectines et certains de leurs dérivés sont donc doués de propriétés galactogènes, $y$ compris par la voie orale et leur effet résulte très vraisemblablement de la stimulation de la sécrétion d'hormones lactogènes.

\section{Références}

ALBERSHEIM P., DARVILL A. G., 1985. Oligosaccharins. Sci. Ame., 253, 44-50.

BOSC M., FÉVRE J., 1975. Evolution de la cortisolémie au cours de la première semaine de vie chez le veau et l'agneau. C. R. Acad. Sci. Paris sér. D, 284, 2373-2376.

EDERY M., HOUDEBINE L. M., DJIANE J., KELLY P. A., 1984. Studies of $\beta$-casein content of normal and neoplastic rat mammary tissues by a homologous radioimmunoassay. Mol. cell. Endocr., 34, 145-151.

HOUDEBINE L. M., 1986. Contrôle hormonal du développement et de l'activité de la glande mammaire. Reprod. Nutr. Dévelop., 26, 523-541.

KANN G., 1971. Radioimmunoassai de la prolactine plasmatique chez la brebis. C. R. Acad. Sci. Paris, 272, 2808-2811.

Mc CLEARY B. V., MATHESON N. K., 1986. Enzymatic analysis of polysaccharide structure. Adv. Carbohydr. Chem. Biochem., 44, 147-195.

OLLIVIER-BOUSOUET M., 1983. Rôle du $\mathrm{Ca}^{2+}$ dans la sécrétion des caséines du lait par la cellule épithéliale mammaire de lapine en lactation. Biol. Cell., 49, 127-136.

SAWADOGO L., 1987. Contribution à l'étude des plantes médicinales et de la pharmacopée traditionnelle africaine : cas des plantes lactogènes. Th. Doct. ès Sci., Univ. F. R. de Tours.

SAWADOGO L., HOUDEBINE L. M., 1987. Induction de la synthèse de caséine- $\beta$ dans la glande mammaire de rates traitées par des extraits de plantes. C. R. Acad. Sci. Paris (sous presse).

THIBAULT J. F., 1983. Etude structurale de substances pectiques à l'aide d'une endopolygalacturonase d'Aspergillus niger : purification, propriétés et possibilités d'utilisation de cette enzyme. Th. Doct. ès Sciences, Univ. de Nantes.

THIBAULT J. F., ROMBOUTS F. M., 1986. Effects of some oxidizing agents, specially ammonium persulfate, on sugar-beet pectins. Carbohyd. Res., 154, 205-216. 